\title{
Predictive Modeling of a Caddo Structure in the Ouachita Mountains, Montgomery Counts, Arkansas
}

Vanessa N. Hanvey

Unknown

Follow this and additional works at: https://scholarworks.sfasu.edu/ita

Part of the American Material Culture Commons, Archaeological Anthropology Commons, Environmental Studies Commons, Other American Studies Commons, Other Arts and Humanities Commons, Other History of Art, Architecture, and Archaeology Commons, and the United States History Commons

Tell us how this article helped you.

This Article is brought to you for free and open access by the Center for Regional Heritage Research at SFA ScholarWorks. It has been accepted for inclusion in Index of Texas Archaeology: Open Access Gray Literature from the Lone Star State by an authorized editor of SFA ScholarWorks. For more information, please contact cdsscholarworks@sfasu.edu. 
Predictive Modeling of a Caddo Structure in the Ouachita Mountains, Montgomery Counts, Arkansas

\section{Creative Commons License}

\section{(c) (1) \&}

This work is licensed under a Creative Commons Attribution-NonCommercial 4.0 International License 


\title{
Predictive Modeling of a Caddo Structure in the Ouachita MOUntains, MONTGOMERY CoUnTY, ARKANSAS
}

\section{Vanessa N. Hanvey}

\begin{abstract}
During the Arkansas Archeological Survey/Society Training Program in June, 2013, an arc of postmolds from a Caddo structure was uncovered at site 3MN298. The site is located in Montgomery County, Arkansas, within the Ouachita National Forest, on a bend of the Ouachita River. After reviewing the literature on Caddo architecture, an attempt was made to predict the size and shape of the building as well as the location of any associated features. In September, 2013, a small field crew effectively ground-truthed the model. This article explores the process of creating and using a predictive model to guide archeological excavations of a Caddo period structure and presents the results of this endeavor.
\end{abstract}

\section{Introduction}

Every June, a large excavation project is conducted by Arkansas Archeological Survey staff as part of the Arkansas Archeological Society Training Program. During this time, Society members take classes from and work alongside Arkansas archaeologists in field and laboratory settings. In 2013, excavations took place at a multicomponent site in Montgomery County, Arkansas, in collaboration with the USDA Forest Service (Figure 1). Site 3MN298 is located on a bend of the Ouachita River, within the Ouachita National Forest, and contains occupational areas dating from the Middle Archaic through Late Mississippian periods (6000 BC-AD 1600). During the Training Program, a Caddo structure was partially uncovered. The Caddo cultural area encompasses southwest Arkansas, northeast Louisiana, east Texas, and southeast Oklahoma, and dates from AD 900-1680.

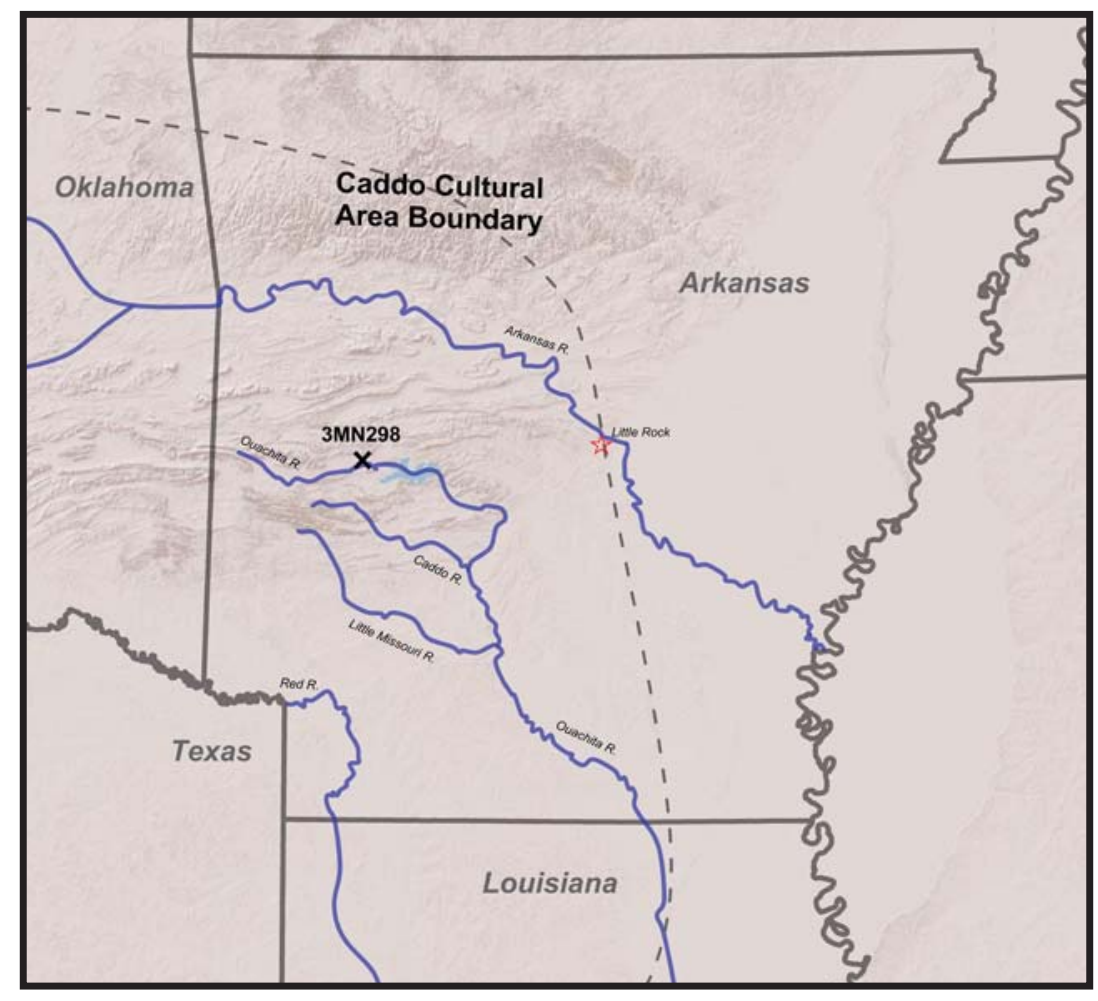

Figure 1. Location of site 3MN298 and Caddo Cultural Area boundary (Perttula 2012). 
The Training Program site was recorded in 1982 after being rip-plowed and planted with pine trees, and limited archaeological testing was conducted in 1985. Timothy Perttula's analysis of over 300 sherds from these excavations dated the main occupation of the site to the Late Mississippian period post-AD 1450/1500 (Perttula 2009b). Shell-tempered sherds constituted $92 \%$ of the sample, and the remaining $8 \%$ was composed of shell/grog, grog, and grog/grit tempered sherds. Though only 13 sherds were decorated, Pertulla was able to type Hodges Engraved, Keno Trailed, Foster Trailed-Incised, or Braden Incised, and one sherd may be Ouachita Ironware dating to the Woodland period. Perttula (2009b:1) writes this is "the largest sherd assemblage from Ouachita National Forest lands in the Ouachita Mountains".

Additional shovel testing was conducted in 2009 and in the preparation for the Training Program in 2012 and 2013 by Meeks Etchieson (FS-ONF), Mary Beth Trubitt (AAS), and Arkansas Archeological Society volunteers. Six separate concentrations of artifacts were identified across the site, and each became an area of excavation during the Training Program. This article focuses on Area 5, located on a terrace approximately $185 \mathrm{~m}$ west of the river and likely southeast of the 1985 excavations. Shovel tests in this location indicated a Caddo occupation and well-preserved faunal material. During the Training Program, over the course of two weeks, 8 excavation units were opened in Area 5 (Figure 2). Though a number of soil stains interpreted as post molds were uncovered, the only apparent pattern was of an arc of post molds likely associated with a Caddo structure.

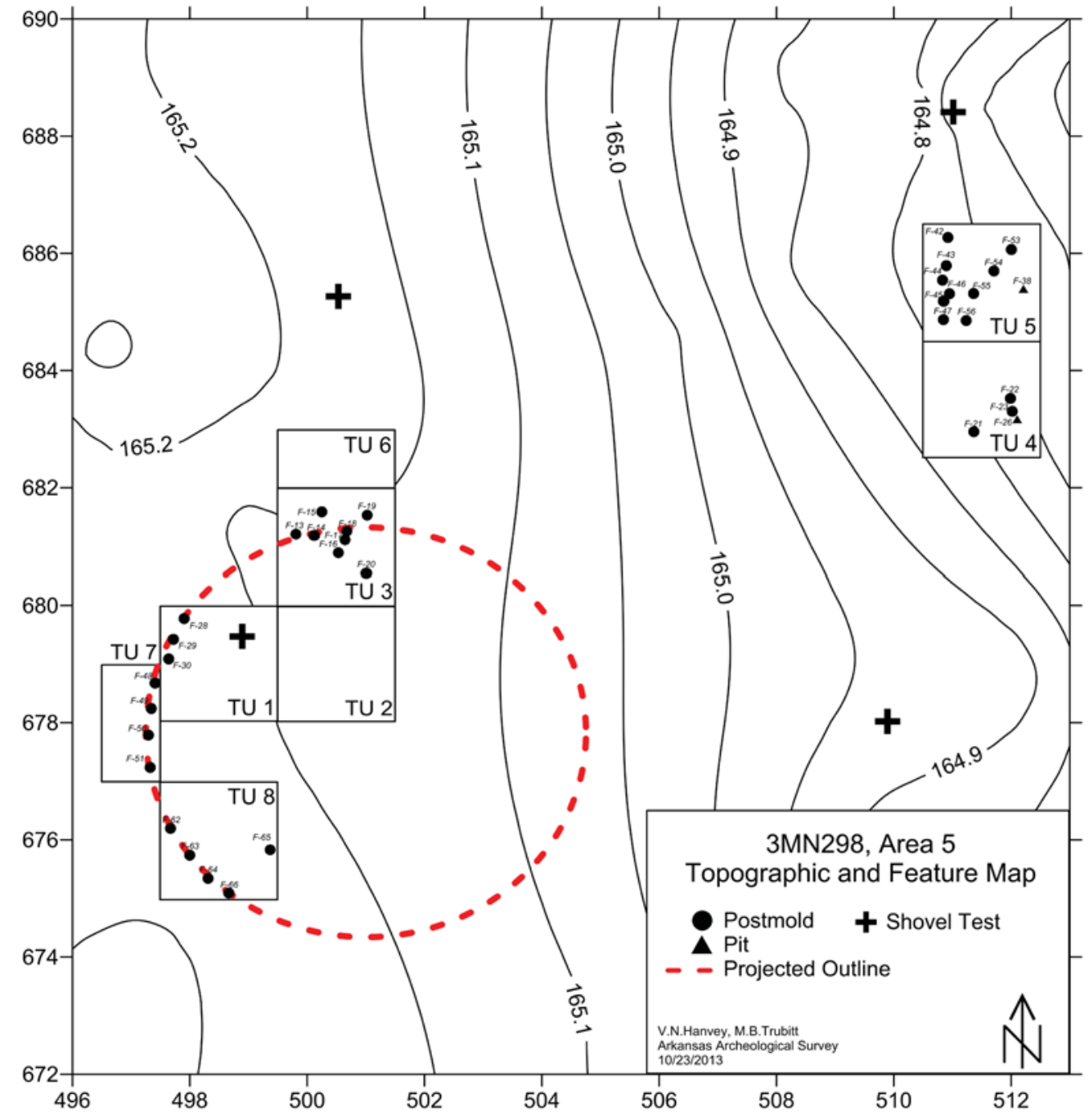

Figure 2. Planview of Area 5 with the features identified in June, 2013, and a projection of the likely structure outline. 
One of the themes of the June excavations was to recover archeological evidence for Caddo Indian lifeways in the Ouachita Mountains. Though features were identified in other areas across the site, Area 5 contained the most intriguing evidence for a complete structure. When extended, the arc of post molds may represent a structure with a diameter of $7.5 \mathrm{~m}$.

Plans were quickly made by Arkansas Archeological Survey and Forest Service staff to return to the site in September to conduct further testing of the area. Our goals were to confirm that this arc was indeed part of a structure, uncover any features associated with the structure, and date the structure through artifact and radiocarbon samples. To aid in this process, a review of Caddo architecture literature, both in the Ouachita Mountains and Ouachita River valley as well as generally in the Caddo Cultural Area, was conducted.

\section{Caddo Architecture}

A domestic structure, or one used throughout the year for primarily residential purposes, would have a different set of architectural features compared with a special-use structure (Early 2000). Early (1988:160) writes these features would be reflective of activities such as "the preparation and storage of food, and a variety of cultural maintenance activities."

Examples of domestic structures not associated with mounds are sparse in the Ouachita Mountains, and none have been excavated on the upper Ouachita River. Interpreted as domestic, a circular structure dating to AD 1250-1350 was identified at the Norman site on the nearby Caddo River (Early and Trubitt 2003; Figure 3). Features associated with the structure included a hearth created from a large postmold or pit and an ash layer distinguishing the floor. At the Hardman site, a Caddo residential compound dating to the late $15^{\text {th }}$ century was excavated containing at least one circular residential structure with a central post mold, other interior post molds, and pit features (Figure 3). The compound was demarcated by a fence, and within this parameter specific use areas were identified by pit features, midden deposits, post mold arcs likely belonging small storage or work facilities, large exterior hearths, and burials (Early 1993). Early (1993:226) writes "except for the fence and the external hearths, this array of features is clearly comparable to historic descriptions of Caddoan farmsteads and is similar to late prehistoric sites tested or excavated elsewhere in the Caddo area." Similar features have helped identify domestic structures at the Cedar Grove, McLelland, and Joe Clark sites in the Red River valley with occupations from 1400-1860 AD (Trubowitz 1984, Kelley 1997; Figure 3).

Rogers (1982:49, in Perttula 2009a) defines a special-use structure as "providing a physical context for the integration of social organization beyond that of the household unit. These may include temples, meeting halls, charnel house, and the residences of chiefs and other officials". Sabo (1998) writes that architectural features, such as controlled entrances, structure size, and central hearths, would reflect the symbolic differences of this type of structure and make it physically stand a part on the Caddo social landscape. Early (2000:160) notes, "activities known to have been carried out in some special structures mirrored domestic activity and are likely to have resulted in a pattern of physical remains that are similar to those expected for domestic dwellings."

Trubitt (2009) discusses the ritual significance of burning and burying buildings with clean fill at the end of their use in the Caddo area, and Early (2000) links this phenomenon with straight-walled structures associated with mounds in the Ouachita River basin. The Adair site is the largest mound site in the area and is situated downriver from the Training Program site (Figure 3). A sequence of 9 structural building, burning, and burying episodes created the principal mound. Two distinct Caddo occupations were identified at the site, the initial was marked with a series of circular buildings, one of which had an extended entranceway. In the 
stratums of the latter occupation, smaller rectangular buildings were identified with some evidence of burning. Other mound sites in the area with similar structure shapes and burning and burying episodes include the Denham, Powell, Caddo Valley, and Hays sites (Trubitt 2009; Figure 3).

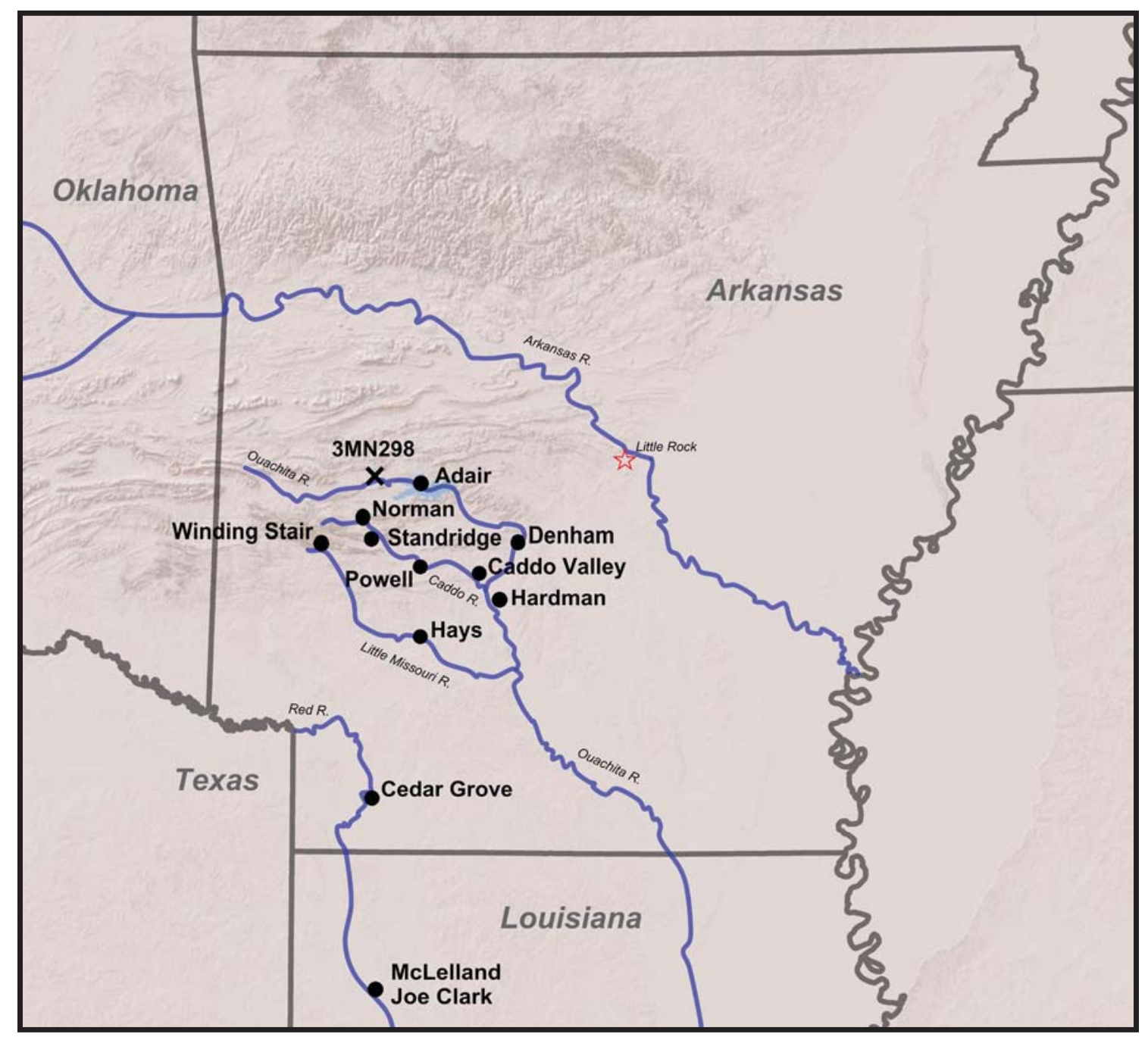

Figure 3. Location of sites mentioned in article.

There is evidence of both circular and rectangular Caddo structures in the Ouachita Mountains, but as Early (2000:70) writes "too few domestic sites have been studied to disclose any pattern of size, shape, and function through time." She goes on to say that at least some domestic structures in the Ouachita Mountains were circular by approximately AD 1350. An example of this would be the structure at the Norman site (Early and Trubitt 2003). In his study of Caddo architectural variability in Eastern Texas, Schultz (2010) examined 265 structures from 31 sites and found $86 \%(\mathrm{n}=186)$ of nonmound structures were circular. Though both circular and square structures have been associated with special-use buildings in mound and non-mound context, Early (2000:129) finds trends within the Ouachita Mountain Caddo area of straight-walled structures being associated with "special" architecture. 
An example of this is the square structure at the Winding Stair site, a nonmound site on the Little Missouri River (Figure 3). Early (2000) interprets the structure as-special use because it is similar to those at the nearby Standridge mound site, and it had the special decommissioning treatment of being burned and buried.

The circular shape compared with other sites in the area, lack of association with a mound, lack of special decommissioning treatment, and associated mundane features in the surrounding area, such as pits and post mold groupings, suggested that the Area 5 structure was a domestic building. The size of the Area 5 structure is on the smaller side for the Caddo area in general, but similar to the structure sizes at the Hardman site.

So, for a domestic structure, I would expect to find interior and exterior post molds marking the locations of raised platforms, interior partitions, exterior granaries, and possibly roof supports (Early and Trubitt 2003, Kelley 1997, and Schultz 2010). There may also be interior or exterior burials, trash and storage pit features, and a central hearth or large post mold.

\section{Predictive Model}

There was a limited field crew during the September project, so test units had to be placed judiciously and numbered based on importance (Figure 4). Test unit 9 was located on the eastern side of the structure in hopes of revealing the wall post mold outline. Test units 10,11, and 13 were located in the center of the structure to uncover a hearth and any other internal features. North of the projected outline of the structure was a conglomeration of post molds. Test units 12 and 14 were located on the northern wall of the structure to uncover the post mold outline and more of the area. Finally, test units 15 and 16 were located on the south and southeast side to uncover the post mold outline and any additional features.

Over a period of 7 days, a total of 6 volunteers, 4 Forest Service employees, and 2 Arkansas Archeological Survey employees helped excavate the units. Area 5 was largely unchanged since June, and the backfilled units are very visible. Due to the rip-plowing, the terrain of the site constituted lines of berms with, in some places, half meter deep furrows. Excavations in June uncovered the depth of the original ground surface beneath the berms in each of the Areas. In September, to save time, the Forest Service used a small trail dozer to scrape the disturbed berm soil off the locations of the new test units.

Profiles of test units excavated in June identified the basic stratigraphy in Area 5, which corresponds to what we encountered in September (Figure 5). The site had been heavily farmed before being plant in pine. Fortunately, the planting process only disturbed the plowzone. Plowscars were in the upper portions of the undisturbed soil, at an approximate elevation of $165 \mathrm{~m}$. Cultural features were not discerned until about $10 \mathrm{~cm}$ below this. 


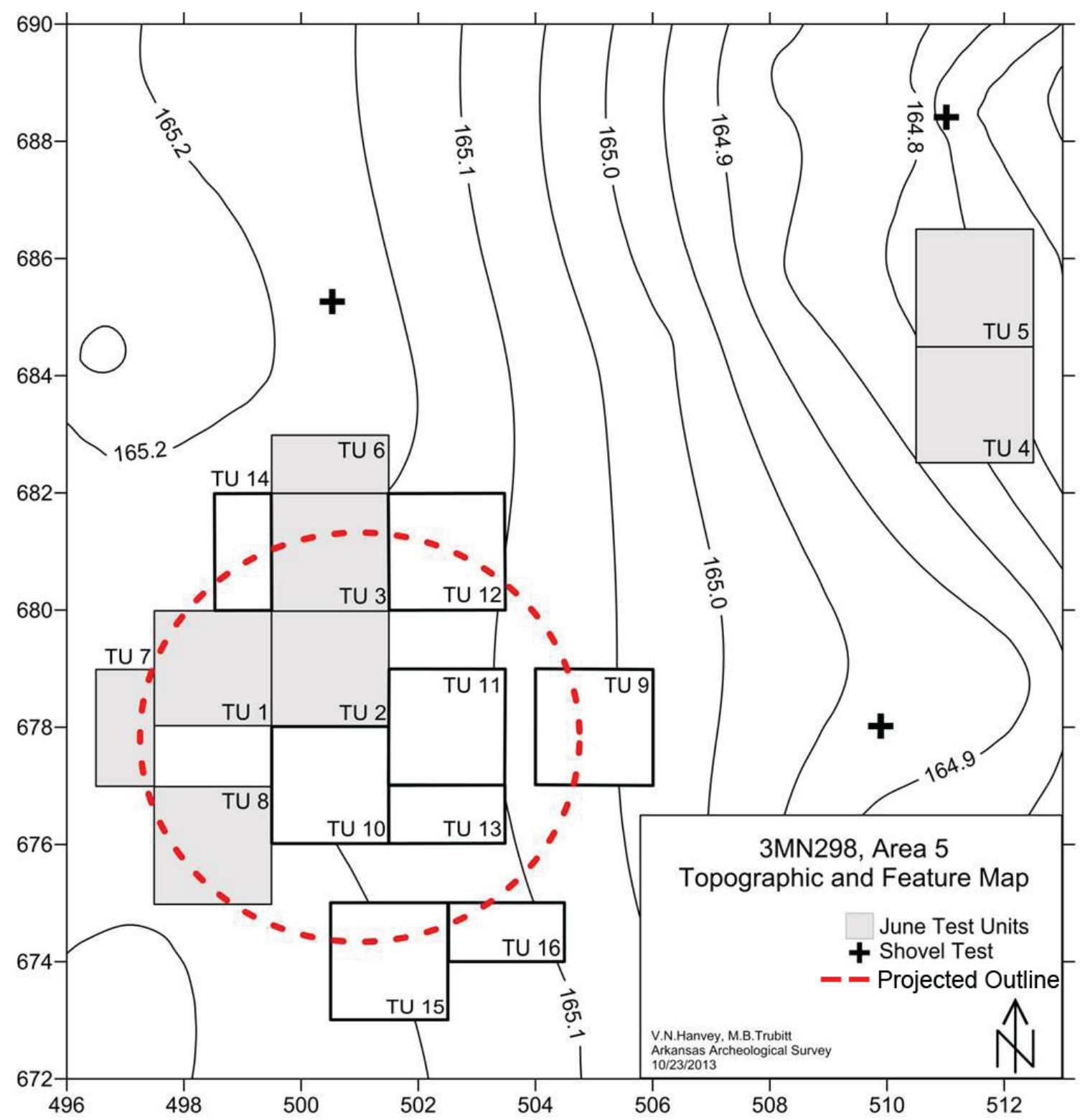

Figure 4. Test unit layout for the September, 2013, excavations and projected structure outline.

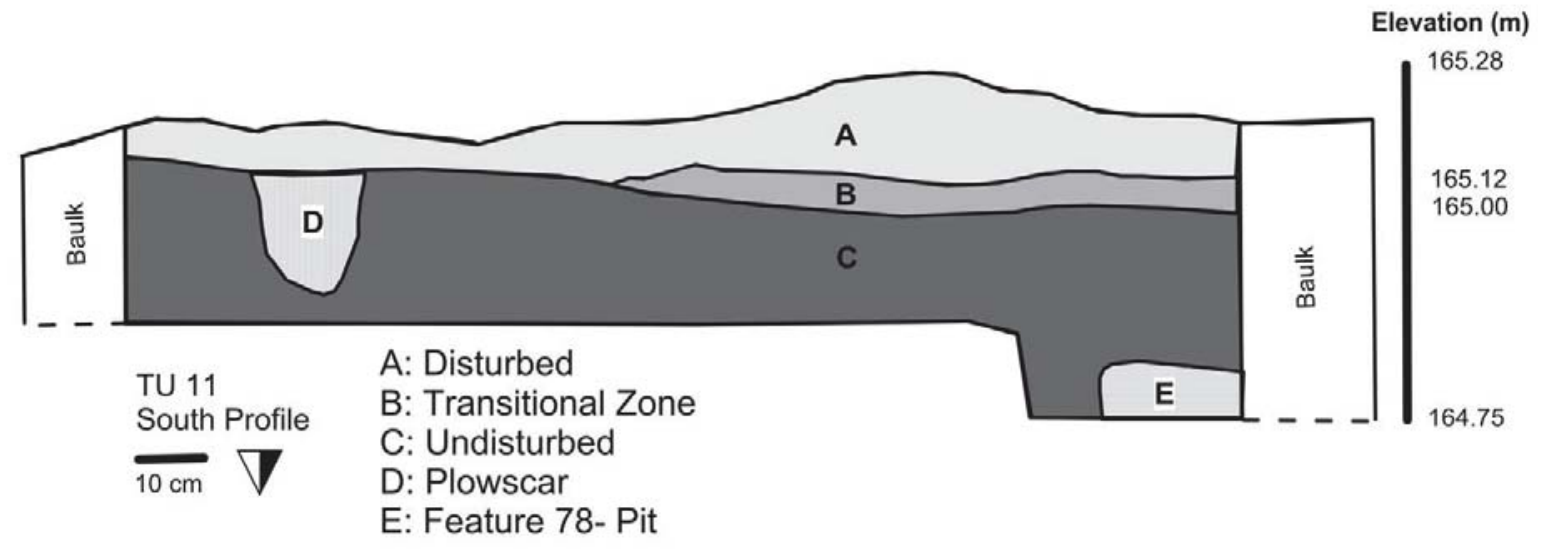

Figure 5. Test unit 11 South wall profile highlighting the basic stratigraphy of the site. 
During excavations in September, the eastern outline of post molds as well as a central hearth confirmed the existence of a structure. A total of 18 distinct features were identified in September, including 8 post molds, 9 soil stains, and a hearth (Figure 6). Evidence of the eastern edge of the structure comes from confirmed post molds and soil stains in test units 9 and 12 . A post mold in test unit 12 had a similar, deep depth as one in test unit 9 (164.67m and $164.64 \mathrm{~m}$; Features 88 and 71). This is contrast to four other post molds in test unit 9 that are much shallower (average $164.77 \mathrm{~m}$; Features $70,72,75$, and 77). When redrawn, the projected outline of the structures intersects both of these confirmed post molds and two soil stains (Features 73 and 74) that are likely postmolds. The other, shallower post molds in test unit 9 may represent a separate structure. Interestingly, this shallow depth corresponds with two post molds in test unit 11 (Features 79 and 89).

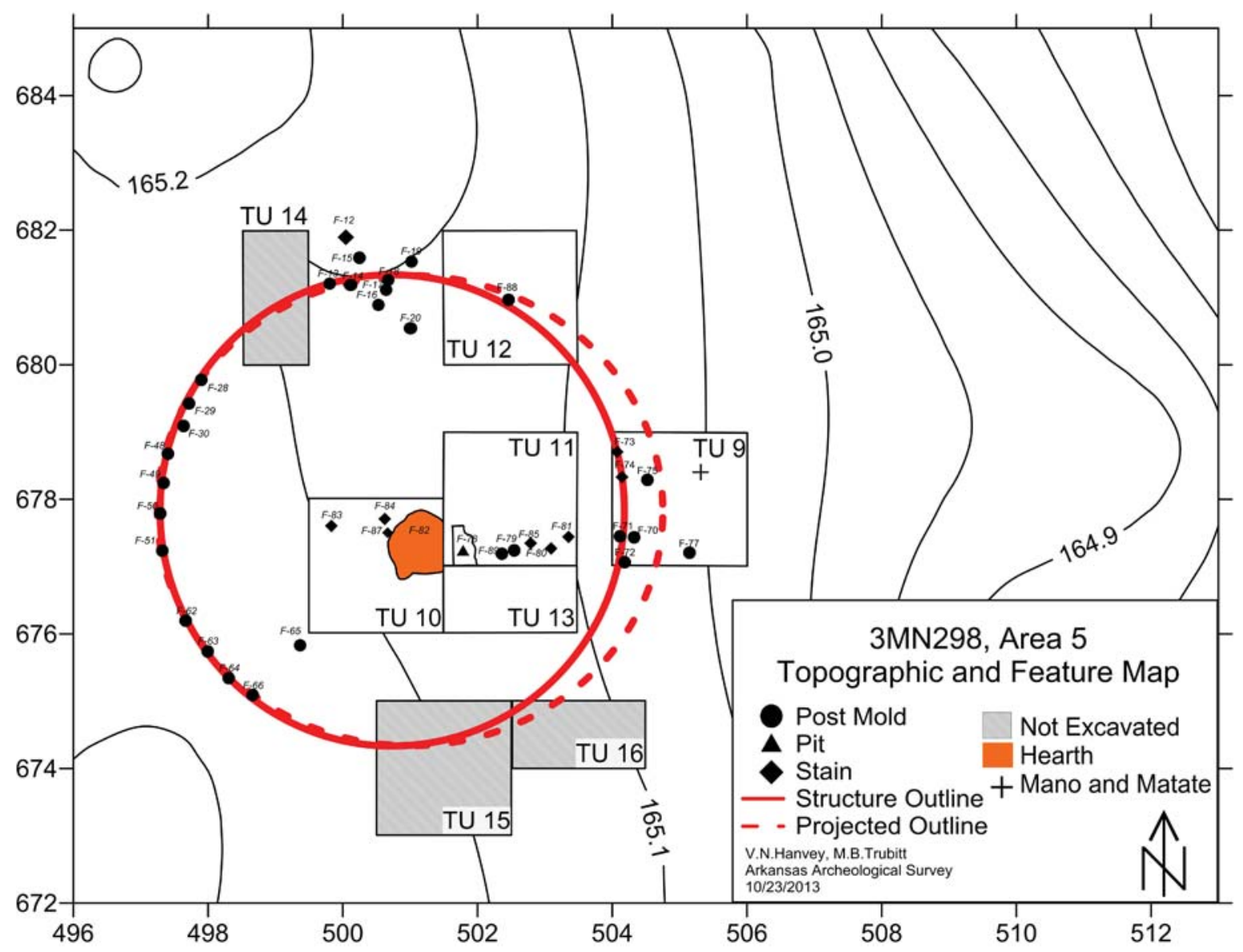

Figure 6. Feature map from the June and September, 2013, excavations and an outline of the confirmed structure.

A hearth was encountered in test unit 10, just southeast of the true center of the structure (Feature 82). Identified by a high density of charcoal flecks and a circular ring of daub at $164.91 \mathrm{~m}$, the hearth had a diameter of $85 \mathrm{~cm}$ and a depth of approximately $30 \mathrm{~cm}$. Outlined by a layer of daub and burned dirt, the central portion of the hearth was filled with charcoal and ash. At the same elevation as the hearth and to the immediate east, a large, possible pit feature was encountered (Feature 78). 
A distinct floor was not encountered in any of the units, though the ground surface of the structure is likely around an elevation of $164.91 \mathrm{~m}$, corresponding to the top of the hearth in test unit 10 and the possible pit feature in test unit 11 (Feature 82 and 78), the top of a sherd cluster and possible pit in test unit 3 (Feature 12), and the base of a mano and matate in test unit 9.

\section{Discussion}

Of the 8 planned test units, 4 were excavated over a period of 7 field days in September, 2013. Post molds corresponding to the projected structure outline were identified along with a hearth, and the structure was confirmed to be $7 \mathrm{~m}$ diameter.

One of the initial problems during the project involved placement of test units between rows of pine trees. This became an issue since our grid was not aligned with the rows. Ultimately most of the units were placed with pine trees only encroaching along the sides.

Due to the limited amount of man-power, test units placed to explore the northern and southern portions of the structure were not excavated. Test units 14, 15, and 16 were all located to explore the projected outline of the structure, and since it appears test unit 9 barely uncovered the eastern boundary, excavating other sides of the structure would have offered more conclusive evidence concerning post mold size and depth. Also, excavating in the test unit 14 location may have shed more light onto the conglomeration of circular soil stains (likely post molds) on the northern edge of the structure.

Only 2 of the likely 18 post molds corresponding to the structure outline were bisected during the June and September excavations. Since the diameters of the stains vary between $13-30 \mathrm{~cm}$, knowing depths would have helped to confirm that all were post molds and all belong to the structure. More data on the depths of post molds would also help clarify the number of structures present.

Artifact and flotation sample analysis are still ongoing from the June excavations. Once complete, this information will add to our interpretations. We are hoping to return to the site for the Training Program in 2014 and further explore Area 5.

\section{Conclusion}

Overall, the predictive model proved successful in locating structural features. Over a period of 7 days, the interior and eastern and northern outlines of the structure were uncovered. The identification of a central hearth provided conclusive proof of the buildings existence.

Further testing in Area 5 in the summer of 2014 might explore the southern and northern portions of the structure as well as to the northeast where a conglomeration of post molds and a pit feature were uncovered in June. The complete excavation of a nonmound Caddo structure and associated features in the Ouachita Mountains, specifically in the upper Ouachita River valley, will greatly benefit architectural literature for this area. Falling between the Arkansas and Red River valleys, investigations into the architecture of the Ouachita Mountains area offers insight into the common cultural heritage of the Caddo peoples. 
Early, Ann M.

\section{References Cited}

1993 Caddoan Saltmakers in the Ouachita Valley: The Hardman Site, edited by A. M. Early, pages 223234. Arkansas Archeological Survey Research Series No. 43. Arkansas Archeological Survey, Fayetteville.

1988 Standridge: Caddoan Settlement in a Mountain Environment. Arkansas Archeological Survey Research Series No. 29. Arkansas Archeological Survey, Fayetteville.

2000 Forest Farmsteads: A Millennium of Human Occupation at Winding Stair in the Ouachita Mountains. Arkansas Archeological Survey Research Series No. 57. Arkansas Archeological Survey, Fayetteville.

Early, Ann M., and Mary Beth Trubitt

2003 The Caddo Indian Burial Ground (3MN386), Norman, Arkansas. Caddoan Archeology Journal 13(2):13-24

Kelley, David B. (editor)

1997 Two Caddoan Farmsteads in the Red River Valley: The Archeology of the McLelland and Joe Clark Sites. Arkansas Archeological Survey Research Series No. 51. Arkansas Archaeological Survey, Fayetteville.

Perttula, Timothy K.

2009a Extended Entranceway Structures in the Caddo Archeological Area. Southeastern Archaeology, Vol. 28, No. 1 (Summer 2009), pp. 27-42.

2009b The Caddo Ceramics from the Dragover Site (3MN298) on the Ouachita River on Ouachita National Forest Lands in Montgomery County, Arkansas. The Arkansas Archeologist, Vol. 48 (2008), pp. 1-14.

2012 The Archaeology of the Caddo in Southwest Arkansas, Northwest Louisiana, Eastern Oklahoma, and East Texas: An Introduction to the Volume. In Archaeology of the Caddo, edited by Timothy K. Perttula and Chester P. Walker, University of Nebraska.

Rogers, J. Daniel

1982 Spiro Archaeology: 1980 Research. Studies in Oklahoma's Past Number 9. Oklahoma Archaeological Survey, Norman

Sabo, George, III

1998 The Structure of Caddo Leadership in the Colonial Era. In The Native History of the Caddo: Their Place in Southeastern Archeology and Ethnohistory, edited by Timothy K. Perttula and James E. Bruseth, pp. 159-174. Studies in Archeology 30. Texas Archeological Research Laboratory, The University of Texas at Austin

Schultz, Thomas Clay

2010 Architectural variability in the Caddo area of eastern Texas. Unpublished Ph.D. dissertation, Department of Anthropology, University of Texas, Austin. (http://repositories.lib.utexas.edu/ handle/2152/ETD-UT-2010-05-912) 
Trubitt, Mary Beth

2009 Burning and Burying Buildings: Exploring Variation in Caddo Architecture in Southwest Arkansas. Southeastern Archaeology, Vol. 28, No. 2 (Winter 2009), pp. 233-247.

Trubowitz, Neal L.

1984 Cedar Grove: An Interdisciplinary Investigation of a Late Caddo Farmstead in the Red River Valley, edited by N.L. Trubowitz. Arkansas Archeological Survey Research Series No. 23. Arkansas Archeological Survey, Fayetteville. 